Central Washington University ScholarWorks@CWU

2005

\title{
The Politics of Forbidden Liaisons: Civilization, Miscegenation, and Other Perversions
}

Stefanie Wickstrom

Central Washington University, wickstrs@cwu.edu

Follow this and additional works at: https:// digitalcommons.cwu.edu/polisci

Part of the Political Science Commons

\section{Recommended Citation}

Wickstrom, S. (2005). The politics of forbidden liaisons: Civilization, miscegenation, and other perversions. Frontiers: A Journal of Women Studies, 26(3) 168-198.

This Article is brought to you for free and open access by the College of the Sciences at ScholarWorks@CWU. It has been accepted for inclusion in Political Science Faculty Scholarship by an authorized administrator of ScholarWorks@CWU. For more information, please contact pingfu@cwu.edu. 


\title{
The Politics of Forbidden Liaisons
}

Civilization, Miscegenation, and Other Perversions

\author{
an essay by Stefanie Wickstrom, Ph.D. \\ Green Mountain College \\ Environmental Studies Department \\ Terrace, 130 \\ One College Circle \\ Poultney, VT 05764-1199
}

\section{BIOGRAPHICAL INFORMATION}

Stefanie Wickstrom has recently been hired as an assistant professor of environmental studies and political science at Green Mountain College in Poultney, Vermont. She has taught Latin American politics, environmental politics, American Indian politics, and Spanish courses. She is currently writing a book that contrasts indigenous nations' experiences with and responses to management of natural resources by settler states (the United States, Panama, and Chile). 


\title{
The Politics of Forbidden Liaisons
}

\author{
Civilization, Miscegenation, and Other Perversions ${ }^{1}$
}

STEFANIE WICKSTROM

\section{INTRODUCTION}

Should we not scrutinize the role of sexual domination in warfare and war's particularly repugnant expression, conquest, before we giddily salute the so-called civilization Europeans introduced into this hemisphere some five hundred years ago? ${ }^{2}$

In this essay, I trace the evolving politics of sexuality in North America and its connections to the expropriation of resources from oppressed populations in what has become the United States of America. To help illustrate the evolution of the politics of sexuality over time, I interpret messages emanating from Sigmund Freud's Civilization and Its Discontents (1930) and Herbert Marcuse's Eros and Civilization (first published in 1955), One-Dimensional Man (1964), and An Essay on Liberation (1969). I offer a comparative interpretation of literary portrayals of forbidden heterosexual liaisons between American Indian men and Anglo women and erotic lesbian liaisons between Latina women. Captivity narratives written by Anglos as they "civilized" North America help to illuminate connections between the oppression of sexuality and the expropriation of resources from American Indians. The women they portray only rarely expressed their own voice — and almost never to declare, define, or celebrate their women's sexuality. Over time, however, we can observe a gradual change in norms governing the sexual conduct of Euroamerican women vis-à-vis Indian men, as civilization comes to dominate the Americas. Celebrations of lesbian sexuality by $20^{\text {th }}$ century Chicana writers constitute a force that opposes oppression of peoples of all genders and ethnic identities. Their voices tell us about the power of love to heal the lives of the exploited and generate a new vision 
of hope for oppressed peoples, and they urge us to recreate the world to make vilification and exploitation unacceptable.

THE POLITICS OF SEXUALITY

The "politics of sexuality" is "the study and practice of or opposition to the oppression of sexuality". 3 Throughout time many different cultures have had many different norms about accepted forms of sexuality. Those who violate norms and engage in forbidden behaviors are “deviants". Deviant behaviors can pose a real threat to the survival and well-being of communities and societies. Whether or not expressions of sexuality are oppressed because they threaten the survival of a particular group, however, those with the power necessary to shape and enforce norms enrich themselves and solidify their authority by emphasizing distinctions between themselves and the deviants that justify expropriation and oppression. Over time, as societies change, so do sexual norms, inclusion of different groups in the "deviant" category, and the logic of oppression. By examining the changing nature of the oppression of sexualities and opposition to oppression, we can learn more about both dynamics of the colonial domination of the peoples of the Americas and the political significance of erotic stories by and about women.

Prominent western psychological and political theories have tried to explain the logic of sexual control by "civilization". Freud believed the control of sexuality was one of the key preconditions for the evolution of civilization. Civilization and Its Discontents describes the "irremediable antagonism between the demands of instinct and the restrictions of civilization" 4 and explains why the individual's sexuality must be controlled by civilization. He admitted that what civilized man considered licentious behavior might indeed be delicious but maintained that it could not be standard practice, or else civilization would be precluded. Norms of sexual conduct that "restrict possibilities of satisfaction" lead to the "replacement of the power of the 
individual by the power of a community", which "constitutes the decisive step of civilization". 5 In Freud's day, westerners commonly believed that American Indians and other "savages" had no morality—hence, no restrictions placed upon their sexuality. They also failed to understand that most American Indian societies had very effective mechanisms to mediate between individual and communal power.

Marcuse's Eros and Civilization was a $20^{\text {th }}$ century response to neo-Freudians who had allegedly, through shallow and prejudiced interpretations of Freud's work, destroyed its revolutionary potential. In Eros and Civilization, Marcuse set out "to demonstrate that beneath the apparent pessimism and conservatism of Freud's thought was an underlying critical tendency ... which contained both a crushing indictment of the established civilization and a promise of ultimate liberation". 6

Marcuse believed capitalism necessitated the devaluation of pleasure, as workers wouldn't simply work for work's sake. ${ }^{7}$ He originally believed that the evolution of civilization would lead to sexual liberation, as laborsaving machinery would gradually eliminate the need for people to work. He later recognized repression in western civilization as "repression in the service of domination" ${ }^{\prime 8}$ and came to believe that sexual repression was a result of the politics of ongoing and non-essential economic exploitation. He hoped that revolution would ultimately lead to the development of "nonrepressive sublimation" that would reconcile the demands of work and pleasure as well as liberate us sexually and politically. (In Freudian/Marcusian terms, "sublimation" means the diversion of the energy of sexual impulse from its immediate goal to a "higher" social use.)

Neither Freud nor Marcuse was especially interested in the control of female sexuality as an evolutionarily adaptive feature of patriarchal cultures. Both discussed patriarchy and male 
domination of the family, communities, and nature, but - Freud in particular — saw them as natural (and universal) consequences of the evolution of civilization. They did not consider patriarchy or the oppression of female sexuality to be related to ways in which certain cultures have organized themselves to solve particular problems of survival. In other words, they were not anthropologists.

Taking a look at the matter through an anthropological-evolutionary-feminist lens, we can see that patriarchal (and patrilineal) western civilization has good reasons to place strict controls on the exercise of female sexuality. When resources and identity are passed from generation to generation from fathers to their sons, the sexual fidelity of wives is important to the survival of men, their families, and their wealth. When the transfer of resources and identity are tied exclusively to the father and his descendants (and not, for example, to the mother's brothers), a wife's infidelity can be especially threatening. From an evolutionary perspective, men in strictly patrilineal societies whose energies are spent on assuring the well-being and eventual successful reproduction of "bastard" children undermine the survival of their own genes. In such societies, monogamy and harsh penalties for unfaithful women are considered logical, rational and beneficial for all. ${ }^{9}$

Freud assumes that all men naturally want to control their sexual objects (known to him as "wives") and that all women are naturally dependent upon their husbands for the well-being of their children. ${ }^{10}$ But, such desires and dependencies are not "natural" at all—especially not in societies where descent is traced through the mother (rather than or in addition to the father) or in communities where women and their children rely upon their mothers' families for material support. In matrilineal and matrilocal societies, for example, women are dependent upon their maternal relatives for the well-being of their children. A brother's investment in the well-being 
of his sister's children assures his own genetic survival. The long-term survival of matrilineal cultures (such as the Zunis in what are today the states of New Mexico and Arizona) illustrates that preservation of social order and the transfer of resources from generation to generation are quite possible without men being concerned about the "legitimacy" of their children or the "infidelity" of their sexual objects.

As their preoccupation with women's sexuality suggests, men in patriarchal societies are quite "naturally dependent" upon women for their survival. Women are incapable of having illegitimate children, but men can be duped into caring for the children of others. If women and their reproductive resources are to remain the useful property of men, wives must be enticed to stay with their husbands and to reproduce only with them. Social controls on the exercise of female sexuality become necessary. Across the world's cultures, types and severity of controls on female sexual expression run the gamut from being no different—quantitatively or qualitatively — from those placed on male sexuality to being quite severe and disabling. Patriarchal societies typically place strict controls on female sexuality. Female genital mutilation is perhaps the most severe form of control. It reduces or eliminates a woman's capacity to experience sexual pleasure so as to encourage obedience to her husband and observance of social restrictions on the exercise of female sexuality. Female genital mutilation is not practiced in matrilineal societies. ${ }^{11}$

Control over expressions of female sexuality is not only key to the orderly transmission of property in patriarchal societies. It also appears to have been essential to expropriation of resources from oppressed populations during colonial conquest. Invading militants have established their dominance over other peoples by committing rape and making sexual captives of women and girls across the world and throughout time. Populations targeted for conquest or 
elimination must not expand at a faster rate than do the populations of their conquerors. Control of the sexuality of the target populations by those pursuing conquest is key. Slaveholders have also used sexual domination to keep majority slave populations under control. ${ }^{12}$ Conversely, as we will see by examining messages about eroticism and sexuality in Indian captivity narratives, Anglo women who were even suspected of breaking established norms and engaging in sexual contact with Indians were condemned by their compatriots - from the establishment of the colonies until the expropriation of American Indian resources by Euroamericans was essentially

complete. Throughout this same time period, Anglo men, though advised against miscegenetic ${ }^{13}$ liaisons with Indians, could conquer an Indian wife's body (for himself) and soul (for Christ), as well as her people's resources, for the "improvement" of all concerned. As Rebecca Blevins Faery so aptly puts it, women's bodies, spiritualities, sexualities, and reproductive capacities have been powerful symbols for the "border zone where cultures in conflict meet and contend, where subjectivities and identities proliferate and coalesce, where discourses of race and gender are generated and played out". ${ }^{14}$

\section{PART I: REPRESSION PRODUCTIVELY INSTITUTIONALIZED}

WHAT IS CIVILIZATION?

According to Freud, civilization "describes the whole sum of the achievements and the regulations which distinguish our lives from those of our animal ancestors and which serve two purposes — namely to protect men against nature and to adjust their mutual relations". ${ }^{15}$ Restricting the individual's powers and possibilities of satisfaction were necessary steps in the process of civilization. Innate human tendencies of all sorts, especially problematic sexual desires, had to be repressed in order to make mankind's achievements possible. Civilization, in 
other words, is repression productively institutionalized. Working and thinking in the late $19^{\text {th }}$ and early $20^{\text {th }}$ centuries in Europe, as Euroamericans were wrapping up the conquest of the Americas, Freud seems to have entertained no doubts that western European civilization represented the pinnacle of mankind's achievements.

Might does not make right, but civilization makes both. That he is advancing civilization — accepted as the outcome of appropriately directed human evolution — is what gives the expropriator the right to take resources that have sustained the savage. Perhaps the greatest moral insecurity of the expropriator is the nagging doubt that the distinction between civilized and savage is fictitious. Justifying expropriation by maintaining the façade of civilization requires that line. When the line begins to blur, difficult questions arise.

Indian captivity narratives enabled Anglo readers to map the illusory territory between civilization and savagery. As the American colonies grew from isolated settlements to encompass the eastern seaboard of North America and expand westward, the "whites' expansion onto Indian lands brought a proximity between whites and Indians requiring caution and the withdrawing of cultural boundaries". ${ }^{16}$ As time passed, more and more Anglos were exposed to Indian cultures - sometimes when they were taken captive during conflicts between Anglos and Indians.

\section{CIVILIZATION AS GOD'S WAY}

The first famous female captive was Mary Rowlandson. She was captured for ransom during King Philip's War by a mixed band of Pocasset, Wampanoag, and Nipmuc Indians in New England in 1675. She took pains in her best-selling narrative about the experience to explain that "not one" of her captors "ever offered the least abuse of unchastity to me, in word or action", when suspicions to the contrary arose. ${ }^{17}$ As with many of the earliest captivity 
narratives, Rowlandson's survival, her chastity while amongst the lustful savages, and her return to civilization are proof of God's will that his faithful be protected and restored to their rightful place after tribulation. King Philip's War resulted in the decimation of New England's indigenous societies and greater opportunities for Anglo settlers to make use of resources that once sustained Indian peoples. Rowlandson served as an important cultural figure-a white woman captured by Indians - used to "justify a brutal colonial politics of removal and extermination" of those who stood in the way of the implementation of God's will for the Americas. ${ }^{18}$

Hannah Swarton's narrative ${ }^{19}$ of her capture in 1690 by Indians on the frontier of New England and sale to French colonists in Canada conveys more lessons about holding close one's religion in the face of adversity. As her afflictions threatened to kill her, Hannah "often thought of the words of our savior to Pilate, John 19.11, 'Thou couldest have no power at all against me except it were given thee from above'," and knew that her own sins had caused God to deliver her into the hands of her captors. ${ }^{20}$ Having survived her tribulations among her captors and the attempts of her French hosts to turn her "papist", Hannah returned safely to New England. ${ }^{21}$

The Rowlandson and Swarton narratives suggest that faithfully abiding by God's laws and patiently enduring suffering were ultimately enough to ensure that savagery could hold no sway over the pious. When civilization was the fruit of faith in the right god, the triumph of civilization would be assured by God's will. Although God sometimes ordained that an Indian maiden become civilized through her marriage to a Christian man, the notion that a Christian woman might adopt the culture of her Indian captor posed a grave threat to Puritan Christianity and the lifeways of the Anglo colonists. 


\section{REMAKING CIVILIZATION IN NORTH AMERICA}

As the contest for control of North America amongst the French, British, Euroamerican settlers, and Indians intensified, many Anglos were captured by Indians during raids and war. Euroamerican settlers became increasingly aware that "white Indians" adopted by their captives sometimes refused to return to life among their Anglo brethren. Enough captive Anglos, especially children, had successfully and happily acculturated to life in American Indian communities to raise doubts about the inherent superiority of civilization and the power of god to deliver Christians from the clutches of savagery. The notion that savagery was "easier to slide into than climb out of" was by then becoming accepted by North America's colonizers as "the prejudice of European Christians toward barbarous primitives was complicated by a concept of cultural evolution that imagined primitive instincts to be incompletely repressed by civilization". ${ }^{22}$ Several explanations were used to account for what might have been a sign that western civilization was not inherently superior - or even that it was a myth. They ranged from the spiritual negligence or inherent laziness of captives to seduction at the hands of Indian lovers. Benjamin Franklin was one who attributed the difficulty in repatriating some white captives to their rejection of the "care and pains" necessary to sustain civilization. ${ }^{23}$

Euroamerican males captured by savages could redeem themselves by coming home and using acquired skills and relationships with Indians to further the American colonial enterprise. Men were much more capable of resuming life among the civilized than were tainted women, who were considered damaged goods. This is explained in part by a norm that held "sexual reputation comprised only an aspect of a man's character, while a woman's identity was wholly defined in terms of her sexual integrity". ${ }^{24}$ As the United States of America came into being, colonizers of Indian lands would create their own unique form of civilization, which would 
empower and reward enterprising men who adapted the more "productive" life ways of the Indians (practices, skills, and knowledge that facilitated subsistence in places remote from those parts of the continent inhabited by the civilized). As this variant of civilization emerged, Indian captivity narratives would continue to captivate American readers.

"Erotica mixed with sadomasochism" 25 entered the captivity narrative genre with the publication of one of the most popular captivity stories of the late $18^{\text {th }}$ and early $19^{\text {th }}$ centuries. Known as the "Panther Captivity" pamphlet, the story was published over 20 times between 1787 and $1814 .{ }^{26}$ Supposedly told to one of the hunters who found her, it is the tale of a "lady taken by the Indians". She has eloped with a lover her wealthy and influential father disapproves of, and the two plan to hide in the wilderness until the father's rage has subsided. Indians then attack them and burn the lover at the stake. She escapes and is captured by a "man of gigantic figure". She kills her captor, decapitates and quarters him and survives by living off the land and in his primitive cave until rescued by Anglo gentlemen years later. The story published in the U.S. was a new twist on a popular legend told at least since the $14^{\text {th }}$ century. In earlier versions, the captor is a giant who lives in the wilderness and speaks a language the damsel cannot understand. By the time of the publication of the 1799 edition of the story, the giant likely symbolized an American Indian. ${ }^{27}$ While capable of outwitting and killing brutal, sexually aggressive Indians, the protagonist is ultimately compliant with the demands of the white male characters in the story. In the end, she is reunited with her dying father, who comes to know of her misfortunes and leaves her a "handsome" fortune.

Interestingly, throughout the story, the woman finds that "the spontaneous produce of the earth" supplies her with food and shelter. ${ }^{28}$ Some feminist interpretations suggest the story projected a positive image of the white woman in the wilderness or reinforced the emerging 
female wilderness cultivator identity associated with pioneer women who moved westward as Euroamericans expropriated lands and resources from American Indians. ${ }^{29}$ Annette Kolodny is one that attributes much significance to the story's portrayal of a feminine way of relating to the wilderness. Whether or not the story's publication marks the emergence of a feminine way of relating to wilderness, it certainly suggests that the young imperial nation was becoming more at home in a landscape that became evermore hospitable as it was subjected to Euroamerican conquest. The formation of the expanding settler state's national identity and the practical demands of conquering a continent had definitely already begun to justify the partial assumption of the lifeways of Indians by Euroamerican men. ${ }^{30}$ Particularly glorified among them were those like Daniel Boone, who could expropriate Indian lands and resources and simultaneously rescue other whites from savages. ${ }^{31}$ The Panther captivity story, published at roughly the same time as John Filson's Daniel Boone story, illustrates that white women could also play an active role in conquering wilderness, even if they were still ultimately dependent upon men.

One of the central messages of the Panther captivity story is that murder of uncivilized males is justified by threats to white women or, more specifically, "threat of sexual contact by an Indian [is] permission for Anglo women to murder and dismember Indian males rather than 'submitting' sexually". ${ }^{32}$ Like the Panther captivity story, "The Adventures of Colonel Daniel Boon, Formerly a Hunter; Containing a Narrative of the Wars of Kentucky" describes the decapitation of an Indian man by a white woman. In Filson's account, when a bold savage ${ }^{33}$ enters the house of a "defenseless" family attended "only" by a Negro man and begins to fight with the Negro, "the mother of the children" enters the fray and cuts his head off. She next defends the door of the house with a gun. A group of armed white men arrive just in time to "pursue the ravagers into the wilderness". Despite the woman's prominent role in defending 
herself and her household, Filson summarizes the incident by noting: "Thus Providence, by the means of this Negro, saved the whole of the poor family from destruction". Both stories illustrate that even the most pioneering Euroamerican women were still indebted for their protection and ultimate well-being to men. Although the protagonist in the Panther captivity story — the fictional creation of a white man—is solely responsible for killing her would-be captor, in the end she is reunited with her father through the efforts of the men who find her. Ultimately, she takes her place as her father's heir. As her adventure is initially a reaction to her father's ambitions, so are her ultimate rescue from the wilderness and long-term well-being accounted for by the determination and the wealth of white men.

SAVAGE OR CIVILIZED, WOMEN AND THEIR SEXUALITY ARE PROPERTY

According to Freud, women are the sexual objects of men. In the context of colonialism, property is acquired by enterprising civilizers who make valid use of what savages have supposedly neglected. Property is then inalienable from conquerors except by established legal procedures. Although Euroamerican men could make use of and enjoy the sexuality of women of color $^{34}$, the thought of Indian men engaging in sexual relations with white women alarmed them. Indian men, one of the enemies with which the young U.S. was battling over resource control, must not usurp the property of Euroamerican men by capturing and sexualizing their women. As European colonizers retreated from North America and the conquest by Euroamericans then proceeded, conflict with American Indians over lands and resources intensified. Although Euroamerican men were in fact expanding their sexual horizons through domination of women of color, Indian men were the ones portrayed as ruthless rapists with extraordinary sexual appetites. ${ }^{35}$ Their white women captives would typically either die heroines resisting Indian sexual advances or be rescued by Euroamerican men. Until the early to mid- 
1800s, a prominent message conveyed by captivity narratives was that miscegenetic relationships between savages and white women, however tantalizing, were harmful to those involved and problematic for Euroamerican society. As Euroamericans expropriated the resources of the indigenous inhabitants of the Americas, controlling women's sexuality remained a related project that both increased the Euroamerican population and kept colonized groups marginalized.

\section{THE CHANGING ROLE OF THE WHITE WOMAN’S SEXUALITY}

As the continental United States came into being, white women became more publiclyacknowledged partners in creating a new national culture wherein whites (male and female alike) enjoyed special privileges. The Native American genocide intensified and surviving Indians were expected to assume the ways of their conquerors. Meanwhile, norms governing sexual relations between white women and Indian men were gradually beginning to change. The stories of Mary Jemison, Frances Slocum, and Eunice Williams, who married Indian men, bore children, and refused to "return to civilization," inspired popular fiction that both conveyed time-worn lessons about the dangers of crossing racial boundaries ${ }^{36}$ and helped Euroamericans begin to grapple with increasingly apparent contradictions between beliefs about miscegenation and the experiences of real people.

In 1824, James Seaver published the story of Mary Jemison's life among the Seneca of western New York. Mary Jemison's narrative was captivating, perhaps most of all because she insisted she had actually loved an Indian. ${ }^{37}$ The story was also problematic because most civilized readers in the early $19^{\text {th }}$ century believed it "unthinkable" that anyone would not want to be restored to civilization if given the opportunity. ${ }^{38}$ Jemison agreed to share her story with Seaver, but he did not simply publish her verbatim descriptions of her Indian husbands or their relationships. Seaver constructed a portrayal of her forbidden liaisons with Indian men that 
reflected existing norms about miscegenation. For example, about her first husband, Jemison supposedly related to Seaver words it is doubtful an octogenarian who self-identified as an Indian since childhood could contrive:

He supported a degree of dignity far above his rank, and merited and received the confidence and friendship of all the tribes with whom he was acquainted. Yet, Sheninjee was an Indian. The idea of spending my days with him, at first seemed perfectly irreconcilable to my feelings: but his good nature, generosity, tenderness, and friendship towards me, soon gained my affection; and, strange as it may seem, I loved him $!^{39}$

For his description of her second husband of many years, Seaver relied on reports from a man who had cheated Mary Jemison out of several hundred acres of land by claiming to be her cousin. George Jemison describes Hiokatoo, a man he never knew, as a bloodthirsty and cruel man from a barbarous society. Seaver uses this account as contrast with the more virtuous Anglo woman with whom Hiokatoo shared his life. ${ }^{40}$

In later versions of the story, traces of Jemison's own voice are replaced by inserted text that contrasts "the Anglo-American Christian with the 'pagan' way and attempt[s] to demonstrate the ultimate victory of the Anglo woman's ways over those of the baser world of 'barbaric' Indians with whom she lived". ${ }^{41}$ As one modern day reviewer of Seaver's story notes, a “machinery of cultural appropriation has intently worked on Mary Jemison's 'narrative,' using appendices, additions, interpolations, illustrations, contextual references, even an account of a deathbed conversion to Christianity — all trying to turn her story, alter it and make it say what she did not say". ${ }^{42}$ Jemison lived as an Indian until her death. She did not tell her story to "remind Anglo-American readers of their racial and cultural superiority". ${ }^{43}$ Her life story was told for her by others. For decades it was a best selling biography that was of more interest to a public enthralled with the persistence of a "captive" woman's Euroamerican traits than to readers who might have wanted to learn about Jemison's adaptation to life among the Senecas. The true nature of her relationships with Indian men, as well as her power as a person, were eclipsed by 
the words of influential white men helping to shape the norms of a burgeoning imperial civilization.

In contrast, Lydia Maria Child's novel Hobomok, which was also published in 1824, is an early reflection in American popular culture of the emergence of new ideas about miscegenation and women's sexuality. Like the work of storytellers before her, Child's story is one of miscegenetic exile from national life that holds the promise of return upon repentance. ${ }^{44}$ Resolution 'requires the 'cooperative' willing disappearance of Indians, through death, removal to the West, or absorption into the white race". ${ }^{45}$ What is different in Child's story is that the disappearance or assimilation of the American Indian is "precipitated ... by the white heroine's marriage to an Indian". 46 Once her Indian husband (and father of her "half-breed" son) disappears along with his race and her son is assimilated fully into Euroamerican culture, Child's protagonist assumes the "right to define her own fate, choose her own religion, reclaim her own sexuality, assert her own worth" ${ }^{47}$ The Euroamerican woman does not suffer, and is not exiled permanently, for exercising her own sexuality and asserting her will. Child's "radical revision of patriarchal script" ends with the heroine's achievement of happiness and the "triumph of alternative values she has embraced" as she "returns to the Puritan community on her own terms, unscathed by her violation of its taboos about miscegenation and divorce". ${ }^{48}$

New norms about Euroamerican women's sexuality and the terms of the assimilation of the American Indian, however, were still not familiar to or popular with most Americans. While over 100,000 copies of Seaver's account of the life of Mary Jemison sold in 1824, Hobomok sold less than 500 copies the same year and was considered by reviewers to be "unnatural," "revolting," and "in very bad taste, to say the least". ${ }^{49}$ Nonetheless, the publication of Child's novel marks a significant change in norms governing the sexual conduct of Euroamerican 
women. The female protagonist's erotic liaison with an Indian actually advances the cause of civilization.

THE EMERGENCE OF A TRANSCONTINENTAL AND MULTIETHNIC NATIONAL CULTURE

By the second half of the $19^{\text {th }}$ century, intimacies between Anglo women and Indian men were becoming a more common theme in popular culture. As Euroamericans- conquered the West and as policymakers advocated the assimilation of remaining Indian peoples into the emergent national culture as a solution to the "Indian problem", stories about intimate liaisons between Anglo women and Indian men helped Euroamericans begin to reconcile old norms with new circumstances.

In stark contrast to the Anglo heroine who refuses to submit to the savage rapist lies the "bosom of white that heaves to the touch" of her "darker", "half-breed" lover in John Rollin Ridge's poem, "The Stolen White Girl”. In the poem, published posthumously in 1968, Ridge celebrates the beauty of forbidden love between a blue-eyed Euroamerican girl and her wild lover of darker complexion. His poem describes the encounter from the perspective of the Indian captor. ${ }^{50}$

Also known as Yellow Bird, Ridge was himself the product of what Euroamerican society characterized as a miscegenetic relationship between a Cherokee man and a Euroamerican woman. His father and grandfather had reluctantly supported removal to Oklahoma as the best option left available to the Cherokee nation as Euroamericans aggressively usurped its traditional territory. (They were both later assassinated by rival antiremoval faction members and Ridge eventually made his way to California, at first to work in the gold fields.) Ridge himself "advocated for the rights of Indians through an assimilationist policy consistent with the ideology of progress so pervasive at the time". ${ }^{51}$ His advocacy, his mixed Indian- 
Euroamerican heritage, and his own ability to live and work relatively successfully in Euroamerican society were no doubt instrumental in making possible his political, journalistic, and literary accomplishments. He was a perfect proponent of change in norms governing intimate relations between Indian men and white women.

Although Ridge's literary accomplishments were recognized and even appreciated in California — where life had long been influenced by a variety of conquistadores and their ambitions, relative ethnic diversity, and the ambiguity of lawlessness in the wild, wild Westwriters advocating Indian rights where Indian nations were fighting U.S. military forces as they attempted to retain control over traditional territories were not as well received. As they laid claim to the resources of peoples they had identified as savages, expropriators continued to use sexual themes to discredit those who claimed that savages were at least "partially civilized", as well as to punish Indians who stood in their way. When Anglos tried to help Indians during conflicts, their advocacy could be explained by sexual loyalties. Erotic vilification was still a useful weapon employed by the imperial Euroamerican nation as it dealt with the Indians.

In the 1860s a white woman's objection to the execution of a Sioux man who had helped her during her captivity ordeal was accounted for by her supposed seduction at his hands during captivity. Sarah Wakefield published the story of her six-week captivity during what became known as the Sioux Outbreak or the Dakota War ${ }^{52}$ of 1862 in Minnesota to protest the U.S. government's treatment of the Indians. Because of this, she "was subjected to the familiar and time-worn accusation leveled at returned captive women: of changed loyalty because of sexual intimacy" ${ }^{\prime 53}$ with their protectors during captivity. Of course it is impossible for anyone to know the true nature of Wakefield's relationship with Chaska, the Indian farmer who protected her and her children during their captivity. Wakefield maintained that it was not a sexual or romantic 
one, and that Chaska only represented to other Indian men that he was her husband to protect her from their supposedly depraved sexual intentions. Her descriptions of life among the Sioux are in no way flattering to their culture. She portrayed Chaska as a "civilized" Indian on the side of the Euroamericans ${ }^{54}$. Despite Wakefield's ongoing attempts to exonerate him and the fact that Chaska apparently had helped the Wakefields from the first moment he found them as they attempted to flee the uprising, he was executed for murder. Wakefield did not become a popular heroine and her captivity story was not a big seller during her lifetime ${ }^{55}$ due to her vilification as an Indian lover.

Paradoxically, one of the reasons that the Indians rose up was to protest Euroamerican traders' sexual abuses of Indian women. The main problem, however, was that administration of Indian affairs by the Northern Superintendency of the U.S. Office of Indian Affairs was subjecting the Indian peoples to hunger as agency traders usurped the annuity payments due them in exchange for their territory by a treaty they had accepted in $1851{ }^{56}$ After the uprising, Indian men were hastily executed for raping Euroamerican women, as Minnesota officials "capitalized on the hysteria focused around the issue of white women captives" 57 to consolidate their control over the region.

\section{WILDERNESS IS CONQUERED}

It is important to note that portrayals of nature in Child's novel Hobomok and in Ridge's poem differ significantly from the Puritan view of nature as prohibitive wilderness. Child's protagonist ritualistically conjures up her Indian lover under the complicit light of the full moon in the woods. ${ }^{58}$ Ridge celebrates the broad prairies, wide woodlands, and deep forests that shelter the lovers' sweet encounter. In his poem, nature becomes, in its various manifestations (the moon, shadows of the forest), the lovers' protector as well as a participant in the pleasure. 
These characterizations suggest an even more definitive turn away from the portrayal of wilderness as prohibitive than, for example, what Kolodny observes in the Panther captivity story. ${ }^{59}$ As North America becomes a store of natural resources, nature becomes property rather than something that must yet be conquered or feared. At the same time that this transformation is accomplished nationwide, controls over Euroamerican female sexuality are eased. The literary works of Ridge and Child represent new constructions of previously forbidden liaisons between Euroamerican women and Indian men. I propose that these constructions could emerge only as the genocide of the American Indians and imperial domination of the lands and resources of North America were well underway.

As the $19^{\text {th }}$ century drew to a close, the vast majority of Native American people had been killed or displaced by Euroamericans. By 1831, the sovereign nations with which the U.S. government had executed treaties had been rendered "domestic dependent nations", and policy makers had found ways to remove them as barriers to imperial expansion. By the late 1830s, Indian nations that occupied territory east of the Mississippi River had been subjected to westward removal. Shortly thereafter, although they had been relocated by Euroamerican policy makers to lands considered essentially useless, thousands of Indian people were killed or forced to assimilate as U.S. military forces claimed the West for Euroamerican settlement and the U.S. fulfilled its Manifest Destiny. By 1890, the conquest of the American Indian nations was essentially accomplished and Indians no longer posed a significant threat to civilization. Their place in the racial hierarchy had been authoritatively established, and whites effectively dominated the expropriation of lands and resources across North America.

After the conquest, strict control of Euroamerican women's sexuality vis-à-vis Indians no longer gave Euroamerican men significant advantages in their political or economic endeavors. 
Sexual repression did, however, continue to help justify the subjugation of racial and ethnic groups competing with Euroamericans for land, resources, and power. ${ }^{60}$ (For example, southerners continued to invoke "the specter of miscegenation to support their efforts to deny freed black people full citizenship and to create a racially-segregated society based on a rule of terror". ${ }^{61}$ ) Gradually, the specter of miscegenation began to flicker and fade into oblivion as women demanded gender equity and sexual freedom, and as exploited racial and ethnic minorities demanded socioeconomic justice during the civil rights era.

Over time, Euroamerican women have progressively been granted more power and privilege in Euroamerican society, but the women's liberation movement neither fully empowered women as sexual subjects nor entirely freed them from sexual repression productively institutionalized. ${ }^{62}$ Norms guiding the expression of female sexualities in the U.S. can still act as barriers to women's development in a range of arenas- from the private to the public, from the personal to the professional. Furthermore, the women's liberation movement has been divided along racial and ethnic lines. Women of color continue to be disproportionately impacted by sexual exploitation, repression, and problematic gender norms.

\section{PART II: LIBERATION—THROUGH PERVERSION?}

I now turn to an exploration of the literary expressions of some Chicanas who have taken the initiative to liberate themselves from repression. They are casting imposed notions of virtue to the winds, celebrating unfettered expressions of female sexualities, and forging bonds with other victims of patriarchy and racism. In contrast with Indian captivity narratives authored by Euroamericans in earlier times, poetry, stories, essays, and plays by contemporary Chicana 
lesbian writers use eroticism to challenge sexual and gender norms and to empower themselves and other victims of exploitation.

Perverse means "turned away from what is right or good" ${ }^{63}$ Like "primitive" or "savage", it is a label designed to set apart behaviors and people considered by the "civilized" to be deviant. Perverse, as used by Marcuse and by me in this essay does not mean harmful or exploitative. Lesbian sexuality is perverse in that it is not widely considered to be right, good, useful, or natural. It is important to note, however, that sexual and gender identities that are not accepted by western civilization are not necessarily unnatural. Again, from an anthropological perspective, human societies exhibit a wide range of norms and beliefs about what natural sexual or gender identities may be and be about. Forms of sexuality considered to be perverse by one social or cultural group are considered to be right, good, useful and natural by others, and can even serve useful purposes (i.e., enhance survival and well-being).

Oppression of any particular expression of human sexuality results more often in the enhancement of the power of dominant social, political or economic actors than in the enhancement of the survival of a community. The development of feminist thought has resulted in a new understanding of sexuality and gender: "Gender is now conceptualized by many feminist theorists as a result of power relations between the sexes rather than as a binary biological category". ${ }^{64}$ For lesbians and other sexually oppressed people, coming out and expressing one's sexual identity means liberating oneself from categories of accepted sexual orientation that can also be understood as both foundations and consequences of exploitative power relations between the sexes and the races.

According to Marcuse, the repression of individual sexuality in the interest of greater productivity under capitalism leads to desexualization of the body in general and the 
"genitalization" of sexuality (infatuation with orgasm). He believed that, with the disappearance of the "pre-technical world", whole dimensions of human activity were "de-eroticized" ${ }^{65}$ Given this sorry state, people long to return to "polymorphous perversity". Marcuse believed that "the sex instinct has no extraneous temporal and spatial limitations on its subject and object; sexuality is by nature "polymorphous-perverse." Sexual mores in western civilization label "perversions" any manifestations of sexuality "which do not serve or prepare for the procreative function". Expression of perversion, then, constitutes a rebellion against "the subjugation of sexuality under the order of procreation, and against the institutions which guarantee this order. ${ }^{66}$ According to Marcuse, perversions "express rebellion against the subjugation of sexuality" ${ }^{97}$ and sexual deviance is "a protest against genital tyranny" and "the social function of the homosexual was analogous to that of the critical philosopher". ${ }^{68}$ He hoped that the resexualization of the body would undo the genitalization of sexuality and "revitalize the libidinal energies of mankind". ${ }^{69}$

In One-Dimensional Man, Marcuse's critique of civilization sharpens. He accuses science of contributing "positively to the ideology of domination and manipulation" by "setting a precedent for the manipulative economic and political enterprises of the modern period". ${ }^{70} \mathrm{He}$ claims that "the scientific method which led to the ever-more-effective domination of nature thus came to provide the pure concepts as well as the instrumentalities for the ever-more-effective domination of man by man through the domination of nature". ${ }^{71}$ As scientific knowledge advances, methodologies can extend rather than subvert pre-established realities. Popular culture and literary expression, too, although they may contain even graphic representations of sexuality, "are in fact conducive to the continued survival of the repressive order in its larger contours". ${ }^{72}$

Ultimately, in An Essay on Liberation, Marcuse advocates revolution and the construction of a free society that would create new incentives and the "unification and 
enhancement of life" for which life instincts are striving. In a new society characterized by "nonrepressive sublimation", life instincts "would provide the libidinal energy for work on the development of a reality which no longer demands the exploitative repression of the Pleasure Principle". ${ }^{73}$ Marcuse wraps up his essay by looking to a young black girl as inspiration for development of the new reality. In answer to the question "which troubles the minds of so many men of good will: what are the people in a free society going to do?", she gets at what Marcuse believes is the "heart of the matter". She replies "we shall be free to think about what we are going to do". 74

\section{ESCAPING REPRESSION WITHOUT LEAVING HOME}

Without relying upon Marcuse (presumably) or leaving their home cultural terrain, Chicana lesbians have tried to liberate themselves from the necessity of repressing their own sexualities. As Chicana lesbian writers disregard established sexual mores and express their "perverse" love for other women, they are, in Marcuse's terms, engaging in protest against genital tyranny. As they celebrate women's sexualities, they are also, as Marcuse predicted, consciously engaged in a revolutionary battle against exploitative economic and political forces.

The rebellion begins with the reconstruction of voice. In her essay, "A Journey toward Voice; or, Constructing One Latina’s Poetics," Cecilia Rodríguez Milanés explains how she began to construct her own form of literary expression as a conscious repudiation of academic writing, which has a voice that is theoretical, analytical, polemic. One of her first publications was edited heavily to remove her own voice: "the editor said she liked my narrative but that she had extensively edited it in order to 'reshape' my words into what she considered to be the

appropriate form" ${ }^{75}$ Chicana writers focused on exploring and expressing women's sexualities have succeeded in establishing their own voices, as Rodríguez Milanés was struggling to do. 
Before setting forth some expressions of Chicana lesbian voices, I should point out that Chicana lesbians are not the only Latina writers who exercise critical, feminist, and erotic voices. Poems, essays, stories and plays by Latina women who do not necessarily identify themselves as Chicanas $^{76}$ or lesbians have helped many women break with civilized gender mores to celebrate their own bodies and sexualities. One scholar has classified these writers as las malcriadas, or wicked women. ${ }^{77}$ An excellent example of taboo-breaking work by a self-proclaimed malcriada is Sandra Cisneros's “Down There”. This poem illustrates Cisneros's capacity to celebrate things that ought not be considered perverse, but that are in a patriarchal society and have, therefore, disempowered women as they experience their own bodies:

... Yes, I want to talk at length about MENstruation. Or my period.

Or the rag as you so lovingly put it. Alright then.

I'd like to mention my rag time.

Gelatinous. Steamy and lovely to the light to look at like a good glass of burgundy. Suddenly I'm artist each month. The star inside this like a ruby. Fascinating bits of sticky I-don't-know-what stuff. The afterbirth without, the birth. The gobs of a strawberry jam. Membrane stretchy like saliva in your hand

It's important you feel its slickness, understand the texture isn't bloody at all. That you don't gush between the legs. Rather, it unravels itself like string from some deep deep centerlike a Russian subatomic submarine, or better, like a mad Karlov cackling behind beakers and blooping spirals. Still with me?

Oh I know, darling, 
I'm indulging, but indulge

me if you please.

I find the subject charming.

In fact,

I'd like to dab my fingers

or a swab of tampax

in my inkwell

and write a poem across the wall.

"A Poem of Womanhood"

Now wouldn't that be something? ${ }^{78}$

Indeed. As they celebrate their bodies and express their voices, Chicana lesbian writers articulate views of women's sexualities that both members of the dominant society and other

Latinos might say go beyond inappropriate to downright perverse:

I was ready to embrace other women.

And feel safe.

And feel a sense of equality.

And feel myself gripping her sensual waist.

Massaging her inviting curves.

Kissing her chocolate nipples.

And sliding my face down

Lick

Down

Lick

Down

Lick

Wanting all of her inside my mouth

And knowing I was never going back

Because honey is

too sweet

To give up. ${ }^{79}$

As this Mónica Palacios poem illustrates, lesbian Chicana writers are redefining the celebration of Latina women and their sexualities. The messages they craft are, therefore, as political as they are erotic.

\section{CHICANA BAD GIRLS}

Three prominent lesbian Chicana writers who have explored and celebrated female sexualities in the struggle to overcome repression are Ana Castillo, Gloria Anzaldúa, and Cherríe 
Moraga. While there are other important literary voices in this genre (such as those of Terri de la Peña and Norma Alarcón), I focus here on the representative work of Castillo, Anzaldúa and Moraga.

Ana CAStillo. Among Chicana writers, Ana Castillo may be one of the best capable of explaining the political with the erotic. Born in 1953 in Chicago, Castillo is a poet, novelist, editor and translator who has written profusely since her youth, speaking "for all women who have at one time or another felt the unfairness of female existence in a world designed by men primarily for men". ${ }^{80}$ She understands sexuality to be an exploration of spirituality ${ }^{81}$ and sees the control of women's sexualities as key to the expropriation of resources from politically repressed populations. Drawing on June Nash's observations about connections between subjugation of indigenous women, racism, and the conversion of "the Aztec caste society into a class system", Castillo characterizes the conquest as a European takeover of control indigenous American men exercised over the productive power of women. ${ }^{82}$ She explains how patriarchal civilization has restricted expressions and enjoyment of women's sexualities.

She claims that lesbianism is less about sex than it is about being free to love outside the confines of sexist and hierarchical parameters. For Ana Castillo, eroticism is about going beyond restrictive boundaries to love. Her work illustrates that the celebration of female eroticism is just as much a terrain open to women as it is to men. Essentially, Castillo appeals to the female reader to consider her own body and her own sexuality as cause for celebration. While her culture and religion, the Chicana lesbian's mother, or a philandering, machista husband may not approve, a woman can express love for women and for herself, and even find connections to the divine through her sexuality. 
Gloria AnZALDÚA. Another of the premier erotic Chicana voices is that of Gloria Anzaldúa. Anzaldúa was born in 1942, a seventh-generation American in a ranch settlement in South Texas. As a young person, she worked alongside her family as a migrant farm worker. ${ }^{83}$

She began to defy boundaries and to rebel early on. She wrote:

My mother says I'm shameless because to me, nothing is private. Maybe that's why I became a writer. My sexual life, my fantasy life, my spiritual life are unveiled, divulged. If there's a veil, it's for myself, but once I realize something, then the whole world can know it. $^{84}$

The whole world came to know about Anzaldúa's work because she became a prominent teacher, Third World feminist theorist, and author.

Anzaldúa's work is definitely sensual and sometimes erotic. She was interested in exploring the boundaries of the human body — and did so from the perspective of a woman. In what some critics have called her obra maestra, Borderlands/La Frontera: The New Mestiza (1987), three poems illustrate her unique portrayal of the woman's body. "Holy Relics" tells the story of the disinterment of the holy body of Teresa de Cepeda Dávila y Ahumada, a nun become saint. Through five disinterments, Teresa's decaying body heals those around her, as she is gradually reduced to a collection of relics for sale. "Compañera, cuando amábamos" is a sentimental and erotic recollection of a love affair with another woman. In a review of Anzaldúa's book, Cherríe Moraga notes that this poem is the only real physical description of lesbian sexuality it contains. ${ }^{85}$ In "Interface," Anzaldúa explores the frontiers between life and other worlds through a woman's body as she describes an experience with "Leyla", a being from another dimension that comes to life through her. Describing her ghost-like friend and their union, Anzaldúa writes where only we existed.

... We lay enclosed by margins, hems,

She was stroking stroking my arms my legs, marveling at their solidity, 
the warmth of my flesh, its smell.

Then I touched her.

Fog, she felt like dense fog,

the color of smoke.

She glowed, my hands paled then gleamed

as I moved them over her.

Smoke-fog pressing against my eyelids

my mouth, ears, nostrils, navel.

A cool tendril pressing between my legs

entering.

Her finger, I thought

but it went on and on.

At the same time

an iciness touched my anus, and she was in

and in and in

my mouth opening

I wasn't scared just astonished

rain drummed against my spine

turned to steam as it rushed through my veins

light flickered over me from toe to crown.

Looking down my body I saw

her forearm, elbow and hand

sticking out of my stomach

saw her hand slide in.

I wanted no food no water nothing

just her-pure light sound inside me... .

Leyla had begun to swell

I started hurting a little.

When I started cramping

she pushed out

her fingers, forearm, shoulder.

Then she stood before me,

fragile skin, sinews tender as a baby birds

and as transparent.

She who had never eaten

began to hunger.... ${ }^{86}$

Anzaldúa defied the categorization of her own sexuality. She said she identified most

\section{with "Chicana dykes," but also claimed}

...I've always been attracted to men. Even now, I'm attracted to men. I'm attracted to children; I'm attracted to animals. When I was at McDowell's ${ }^{87}$, I made love to a tree. 'Lesbian' is the nearest thing that identifies me, but I don't know what I am. 'Lesbian' is not an adequate term. ${ }^{88}$ 
The polymorphous-perverse Anzaldúa strived to enable women of color to accept and love themselves for whatever they might be. She died of complications related to diabetes in May 2004 at the age of 61 .

Cherrít MoragA. Moraga was born in 1952. She is la güera, the daughter of a Latina mother and an Anglo father from California. A poet, essayist, editor, storyteller and playwright, she is credited for "coming out as a lesbian in print" and "putting the Chicana lesbian onstage for the first time in the history of the Chicano theater movement". ${ }^{89}$ Besides This Bridge Called My Back, her most famous book is Loving in the War Years: lo que nunca pasó por sus labios (Boston: South End Press, 1983). The book is an attempt to say what hasn't been said. That "involves the textual construction of the lesbian body and lesbian desire as well as the destruction of conventional codes that govern the representation of female desire and the female body". It reflects the Chicana lesbian's "struggle with the internalization of oppressive attitudes and representational codes in the area of sexuality as well as in those of race, culture and class". ${ }^{90}$ Eroticism is portrayed in the poetry and the stories of the book, but - once againMoraga's exploration of lesbian sexuality and Chicana identity emerges as a commentary on oppression and the politics of sexuality.

THIS BRIDGE CALLED MY BACK. Moraga, Anzaldúa, and Castillo are jointly responsible for publishing one of the first feminist manifestos by women of color, This Bridge Called My Back: Writings by Radical Women of Color. In "Refugees of a World On Fire: Foreword to the Second Edition," Moraga notes that the book concentrates on relationships between women to provide "some basic consciousness so that heterosexism and sexism are not considered the normal course of events". ${ }^{91}$ This puts Chicana lesbians "in a much stronger position to analyze 
our relations with the men of our families and communities from a position of power rather than compromise". ${ }^{92}$ The poems, stories and essays that comprise the book all describe and celebrate both the erotic and political significance of love between "Third World" women. The point, Anzaldúa tells us in her "Foreword to the Second Edition," is to thaw hearts and change consciousness. Later, in her essay entitled "La Prieta," Anzaldúa goes on to explain:

The rational, the patriarchal, and the heterosexual have held sway and legal tender for too long. Third World women, lesbians, feminists, and feminist-oriented men of all colors are banding and bonding together to right that balance. Only together can we be a force. I see us as a network of kindred spirits, a kind of family.

We are the queer groups, the people that don't belong anywhere, not in the dominant world nor completely within our own respective cultures. Combined we cover so many oppressions. But the overwhelming oppression is the collective fact that we do not fit, and because we do not fit we are a threat. ${ }^{93}$

\section{LIBERATION AND PERVERSION}

Perhaps most Latina lesbians "have not politicized their desires nor openly declared them as a way of life", ${ }^{94}$ but Chicana lesbian writers have articulated a powerful cultural critique that "exemplifies disobedience, a metaphor for disruption of the social construction, and points toward social change". ${ }^{95}$ By exercising the right to love whom they please and to celebrate that love as beauty, Chicana lesbian writers are consciously working to liberate themselves and others from boundaries imposed on their sexualities by a hierarchical, racist and sexist order that works simultaneously to expropriate their resources. Humble and enduring Latina woman as obedient wife and nurturing mother is replaced by a powerful sexual being who celebrates the female body. Castillo, Anzaldúa and Moraga have worked to heal themselves and offer hope of liberation from sexism and a more fulfilling sexuality to other Latina women. In Marcusian terms, they have apparently succeeded in resexualizing their bodies (perhaps Anzaldúa above all), but have they escaped the genitalization of sexuality or managed to find liberation from civilization? 
It is too bad that Freud could not read Castillo. She certainly understands the objectification of women and their bodies. She writes that romance, "an archaic carryover from the time when woman was even further reduced to 'object of desire,' is still an important part of sex for heterosexual women". ${ }^{96}$ She goes on to explain how even lesbians are trapped by sexual identities imposed on women when society is "defined in patriarchal terms". ${ }^{97}$ The butch/fem dichotomy leads to oppression of lesbian by lesbian — the result of "loving in a world governed by strict roles and where sex is more associated with dominance and submission than with giving and receiving pleasure". ${ }^{98}$

Nonetheless, within lesbian relationships, "there is a prevalent transgression of the restrictions upheld by hierarchical society". ${ }^{99}$ Writings by Latina malcriadas and Chicana lesbians, for example, celebrate sex and orgasm—while, according to the norms of more traditional Latino culture, women are restricted from enjoying sex and some even pride themselves on their lack of orgasms. Some of the erotic portrayals of women they produce seem to be focused intensely on traditional objects of male desire (breasts, hips, buttocks), but Chicana lesbians also reinterpret women's bodies and recreate the sexual landscape. In this new vision of sexuality, the point of sex is not the orgasm, but the celebration of the rediscovery of women's sexualities. It seems safe to conclude that most erotic writings by Chicana lesbians, by celebrating diverse aspects of love and varied aspects of their female subjects, are working to undermine the genitalization of sexuality.

Are radical Chicana lesbians working, as Freud might fear, to undermine the power of the community as they engage in "perversion", expand their own possibilities of satisfaction, and struggle to redefine sexuality? It seems they are exposing and undermining oppressive aspects of Latino culture in their struggle. But, as they rebel against traditional norms that have governed 
the formulation of women's identities and expressions of sexuality, they are striving to remake their communities along lines that allow all people access to pleasure, love, valuation, and acceptance. Although some may characterize it as an "attack" on tradition, challenging oppressive gender roles and celebrating the full range of diverse human sexualities cannot undermine community. These are critical first steps in the process of overthrowing the overarching hierarchical order that facilitates expropriation of the resources of oppressed internal colonies of the United States, which are defined as much by gender as by race.

The Chicana lesbian writers discussed here have escaped their lot in civilization. They are recognized writers and thinkers who enjoy economic security. Anzaldúa, in particular, could be touted as a success story, since she was born into a family near the very bottom of the socioeconomic ladder that labored long and hard to put food on the tables of the "higher dogs." Many Latinos strive successfully to become part of the socioeconomic elite so they too can enjoy civilization's benefits. Those who attempt to escape civilization are rare. Those who attempt to reconstruct it are rarer still. Being Latinos, homosexuals, and women, however, these Chicana lesbian writers have fully experienced exclusion, or being the irreconcilable "other". They understand the dangers of civilization. They have experienced the process of dehumanization for the sake of expropriation and have written about that and about connections between expropriation and oppression of women's sexualities.

Moraga and Anzaldúa have directly addressed concerns about how they have oppressed others and about how they can stop oppression and form bonds between exploited people. In her essay, "La Güera," Moraga writes that if we come to terms with what it feels like to be a victim ... it would be impossible to discount the oppression of others, except by again forgetting how we have been hurt.

And yet, oppressed groups are forgetting all the time.... Because to remember may mean giving up whatever privileges we have managed to squeeze out of this society by virtue of our gender, race, class, or sexuality. 
Within the women's movement, the connections among women of different backgrounds and sexual orientations have been fragile, at best. I think this phenomenon is indicative of our failure to seriously address ourselves to some very frightening questions: How have I internalized my own oppression? How have I oppressed? ${ }^{100}$

Anzaldúa got more explicit:

It is difficult for me to break free of the Chicano cultural bias into which I was born and raised, and the cultural bias of the Anglo culture that I was brainwashed into adopting. It is easier to repeat the racial patterns and attitudes, especially those of fear and prejudice, that we have inherited than to resist them....

...We fear our power, fear our feminine selves, fear the strong woman within, especially the black Kali aspect, dark and awesome. Thus we pay homage not to the power inside us but to the power outside us, masculine power, external power.

I see Third World peoples and women not as oppressors but as accomplices to oppression by our unwittingly passing on to our children and our friends the oppressor's ideologies. I cannot discount the role I play as accomplice, that we all play as accomplices, for we are not screaming loud enough in protest. ${ }^{101}$

While they may not yet have managed to liberate themselves from civilization, it's clear that these Chicana lesbian writers are screaming in protest.

\section{CONCLUSIONS}

Freud would likely overlook — while Marcuse would surely appreciate — what we can learn from mapping the politics of sexuality through interpretation of erotic stories told by women. Stories about liaisons between Anglo women and Indian men conveyed beliefs that justified the expropriation of Indian resources. Returned female captives who were given voice through publication of their stories were enabled, principally, to deny having sexual encounters with Indian men. They wrote about the rewards of resisting the advances of the savages. Heroines resisted and deviants succumbed to temptation. Stories about women taken captive by Indians helped to reinforce norms about appropriate boundaries between the civilized and the savage. 
As time went on, captivity narratives were written to explore those boundaries, which were becoming increasingly illusory. Although erotic liaisons between Indian men and Euroamerican women became more common in fact and more popular in print in the 1700s, they were still portrayed as threatening. Until whites had established a definitive racial hierarchy and control over the resources of North America—natural, human, and sexual—control over women's sexuality was strict. The women portrayed in the captivity narratives were clearly sexual objects. The female "victims" of savage males driven by diabolical passions rarely expressed their own voices on the early American frontiers. When they did, their words were usually confusing, condemning, or rewritten.

As the conquest proceeded, the American public became more interested in both forbidden liaisons and their cultural and normative implications. Though her biography was written for her, Mary Jemison managed to share some of what she experienced living as a "white Indian", even if readers were more interested in the perseverance of her Euroamerican traits than learning about Seneca culture. Sarah Wakefield emphatically explained in what appears to have been her own voice that, even though they were culturally inferior to Anglos, Indians could be good people.

The possibility of an erotic encounter between an Anglo character and her Indian captor made captivity narratives interesting and marketable to the burgeoning Euroamerican public. Lydia Maria Child and her publisher may have best appreciated this. Until the publication of Hobomok, the predominant message emerging from narratives about forbidden liaisons was that they had problematic consequences for Indian men and white women alike. Whether or not Child was an analyst of the politics of sexuality that disempowered women and Indians in her day, her writing reflects the emergence of new norms about women's sexuality. 
I believe these norms could become widespread only once the expropriation of the lands and resource bases of the American Indian nations was nearing completion. Once American Indian men could be assimilated into Euroamerican culture on terms imposed by their conquerors, they could be included in dominant social arrangements — even marriages with white women. They no longer posed a threat to the orderly transmission of resources, which by then were becoming the property of dominant whites.

As Child may have been struggling to do, Chicana lesbian writers like Castillo, Anzaldúa, and Moraga generate a new vision to replace the repressive order into which they were born. Their stories convey messages to other exploited people about the necessity of overturning civilization and recreating a world where there are no "others" from whom it is acceptable to expropriate natural, human, or sexual resources. In Marcusian terms, they are exploring the uncharted territory of nonrepressive sublimation. They seem to have plenty of libidinal energy to help construct a new reality that no longer demands exploitative repression of the "Pleasure Principle". ${ }^{102}$ Much more coherently than Child in Hobomok or Freud in Civilization and Its Discontents, Chicana lesbian writers are formulating a "crushing indictment of the established civilization and a promise of ultimate liberation". ${ }^{103}$

We still have much to accomplish if we are to reach the pinnacle of humankind's achievements. We can achieve liberation as individuals and as communities only when patriarchy and hierarchy are recognized as real threats to well-being — not when they are most "productively" institutionalized. Erotic stories told by women have played an important role in promoting liberation by helping us see forbidden liaisons through alternative lenses. They empower us to envision and, ultimately, create a world wherein sexualities, identity, and the organization of human productive activity need not be repressed or controlled to 
disproportionately benefit any particular race or gender. Furthermore, the women portrayed in these stories, along with their writers, cease to be sexual objects and become free sexual subjects. For individuals and for communities, liberation is possible only when nature and women are revered and respected, resources are shared, and love erases erotic vilification along with the artificial distinctions of "civilized", "savage", and "perverse".

\footnotetext{
${ }^{1}$ Special thanks go to three colleagues at Central Washington University: to Rachel Pybon, my first student research assistant, whose interest in the subjects covered here was inspiration; to Anne Denman for giving me a chance to teach women's studies; and to Stella Moreno, who invited me to begin writing about la mujer y lo erótico. Thank you also to the anonymous reviewers at Frontiers, whose comments helped me clarify and strengthen my analysis and discussion.
}

${ }^{2}$ Stephanie Wood, "Sexual Violation in the Conquest of the Americas," in Sex and Sexuality in Early America, ed. Merril D. Smith (New York: New York University Press, 1998), 9.

${ }^{3}$ Tim Edwards, Erotics \& Politics: Gay male sexuality, masculinity and feminism (London: Routledge, 1994) 37_emphasis mine. In contrast, according to Edwards, "sexual politics" is the study and practice of or opposition to gender oppression.

${ }^{4}$ Sigmund Freud, Civilization and Its Discontents, translated by James Strachey (New York: W.W. Norton \& Company, Inc., 1961), 6.

${ }^{5}$ Ibid., 42.

${ }^{6}$ Paul A. Robinson, The Freudian Left: Wilhelm Reich, Geza Roheim, Herbert Marcuse (New York: Harper \& Row, Publishers, 1969), 196.

${ }^{7}$ Ibid.

${ }^{8}$ Ibid., 203.

${ }^{9}$ See Else L. Hambleton, “The Regulation of Sex in Seventeenth-Century Massachusetts: The Quarterly Court of Essex County vs. Priscilla Willson and Mr. Samuel Appleton," in Sex and Sexuality in Early America, ed. Merril D. Smith (New York: New York University Press, 1998), 89-115. Hambleton points out that exercise of sexuality by either gender outside the confines of marriage threatened the "orderly transmission of property" and uses that argument to explain prohibitions against fornication in Puritan culture. She also explains that it was the relatively 
powerless women who were typically convicted and punished for fornication. The lives of married women were forever transformed by the stigma associated with the convictions. It was unusual for any Puritan man to take financial responsibility for a condemned woman and her illegitimate child. Men accused of fornication could usually successfully deny paternity and avoid the obligation to care for an illegitimate child. I contend that this means that most men were spared any risk of investing in another man's progeny. Puritan men avoided the risk and Puritan women shouldered the burden of sustaining the patriarchal arrangement.

${ }^{10}$ Sigmund Freud, Civilization and Its Discontents.

${ }^{11}$ Alice B. Child and Irvin L. Child, Religion and Magic in the Life of Traditional Peoples (Prentice Hall: New Jersey, 1992).

${ }^{12}$ Trevor Burnard, "The Sexual Life of an Eighteenth-Century Jamaican Slave Overseer," in Sex and Sexuality in Early America, ed. Merril D. Smith (New York: New York University Press, 1998), 163-189.

${ }^{13}$ According to Sizer, the term miscegenation was invented and first used in 1863 to describe interbreeding between Anglos and non-Anglos. It now applies to sexual relations between any presumably distinct races. For an interesting discussion of how Democrats created the term in 1863 and used it in a pamphlet extolling the virtues of miscegenetic unions in an effort to scare voters away from President Lincoln, see Lyde Cullen Sizer, "Still Waiting: Intermarriage in White Women's Civil War Novels," in Sex, Love, Race: Crossing Boundaries in North American History, ed. Martha Hodes (New York: New York University Press, 1999).

${ }^{14}$ Rebecca Blevins Faery, “Legacy Profile: Mary Rowlandson (1637-1711)," Legacy 12, no. 2 (1995), 127.

${ }^{15}$ Sigmund Freud, Civilization and Its Discontents, 36.

${ }^{16}$ June Namias, White captives: gender and ethnicity on the American frontier (Chapel Hill: The University of North Carolina Press, 1993), 97.

${ }^{17}$ Gary L. Ebersole, Captured by Texts: Puritan to Post-Modern Images of Indian Captivity (Charlottesville: University Press of Virginia, 1995), 17. Also see Gordon M. Sayre, ed., American Captivity Narratives: Selected Narratives with Introduction/Olaudah Equiano, Mary Rowlandson, and Others (Boston: Houghton Mifflin Company, 2000).

${ }^{18}$ Rebecca Blevins Faery, "Legacy Profile: Mary Rowlandson (1637-1711)," 127.

${ }^{19}$ Swarton's narrative was written for her by Protestant Minister Cotton Mather, who was the son of Increase Mather, the Puritan clergyman who sponsored Mary Rowlandson's narrative. 
${ }^{20}$ Gordon M. Sayre, ed., American Captivity Narratives: Selected Narratives with Introduction/Olaudah Equiano, Mary Rowlandson, and Others, 187-8.

${ }^{21}$ Gordon M. Sayre, ed., American Captivity Narratives: Selected Narratives with Introduction/Olaudah Equiano, Mary Rowlandson, and Others.

${ }^{22}$ Ibid., 12.

${ }^{23}$ In Annette Kolodny, “Among the Indians: The Uses of Captivity,” Women's Studies Quarterly XXI, no.s 3 \& 4 (1993): 184-195.

${ }^{24}$ Else L. Hambleton, “The Regulation of Sex in Seventeenth-Century Massachusetts: The Quarterly Court of Essex County vs. Priscilla Willson and Mr. Samuel Appleton,” 104.

${ }^{25}$ June Namias, White captives: gender and ethnicity on the American frontier, 94.

${ }^{26}$ Kathryn Zabelle Derounian-Stodola, ed., Women's Indian Captivity Narratives (New York: Penguin Books, 1998).

${ }^{27}$ Derounian-Stodola asserts that the 1799 story's giant “certainly possesses Indian attributes" and can be tied to "Native American lore about the ritual killing of a fertility god". See Kathryn Zabelle Derounian-Stodola, ed., Women's Indian Captivity Narratives, 84. Annette Kolodny suggests that the giant's ethnicity is intentionally "unidentified" (emphasis in original). Kolodny argues that the giant represents the "uncivilized brutality of wilderness". She claims the symbolic oppositions in the story "are not so much between civilized European associations and the Indianized wilderness as they are between different ways of being in and relating to the vast American landscape", which are represented by the female cultivator and the male hunter. See Annette Kolodny, “Turning the Lens on 'The Panther Captivity': A Feminist Exercise in Practical Criticism,” Critical Inquiry 8, winter (1981), 338, 343.

${ }^{28}$ Kathryn Zabelle Derounian-Stodola, ed., Women's Indian Captivity Narratives, 88.

${ }^{29}$ Kathryn Zabelle Derounian-Stodola, ed., Women's Indian Captivity Narratives; Annette Kolodny, “Turning the Lens on 'The Panther Captivity': A Feminist Exercise in Practical Criticism”'.

${ }^{30}$ Annette Kolodny, “Turning the Lens on 'The Panther Captivity': A Feminist Exercise in Practical Criticism”; Greg Sieminski, "The Puritan Captivity Narrative and the Politics of the American Revolution," American Quarterly 42, no. 1 (1990): 35-56. 
${ }^{31}$ The text of "The Adventures of Colonel Daniel Boon, Formerly a Hunter; Containing a Narrative of the Wars of Kentucky" is available at the Archiving Early America website at http://earlyamerica.com/lives/boone/ (accessed May 1, 2005).

32 June Namias, White captives: gender and ethnicity on the American frontier, 94.

${ }^{33}$ It is important to note that throughout the course of telling his story, Filson does not once use the term "man" or "men" to refer to Indians. He calls them "Indians" or uses derogatory or hostile descriptors including "savages" and "the enemy". Filson does, however, refer to the Negro as a "Negro man" once when he introduces him.

${ }^{34}$ As slavery became an integral part of the colonial enterprise, Anglo men in North America exerted increasing control over the sexuality of the women of color they dominated. As slaveholders (and, earlier, encomenderos-the grantees that received the right to exploit Indian labor in colonial Spanish America from the crown under the encomienda system, which lasted from 1503 into the late $18^{\text {th }}$ century) took advantage of their female captives, white male sexual fantasies became focused on colored women rather than white women. See, for example, Trevor Burnard, “The Sexual Life of an Eighteenth-Century Jamaican Slave Overseer,” 165.

${ }^{35}$ June Namias, White captives: gender and ethnicity on the American frontier.

${ }^{36}$ Rebecca Blevins Faery, Cartographies of Desire: Captivity, Race, and Sex in the Shaping of an American Nation (Norman: University of Oklahoma Press, 1999). According to Blevins Faery, inspired popular fiction includes Eastburn and Sand's epic poem, Yamoyden: A Tale of the Wars of King Phillip (1820), Sedgwick's Hope Leslie (1827), and Cooper's The Wept of Wish-Ton-Wish (1829).

${ }^{37}$ Annette Kolodny, “Among the Indians: The Uses of Captivity,” 191.

${ }^{38}$ Gordon M. Sayre, ed., American Captivity Narratives: Selected Narratives with Introduction/Olaudah Equiano, Mary Rowlandson, and Others.

${ }^{39}$ Kathryn Zabelle Derounian-Stodola, ed., Women's Indian Captivity Narratives, 147.

${ }^{40}$ June Namias, White captives: gender and ethnicity on the American frontier.

${ }^{41}$ Ibid., 156.

${ }^{42}$ Neil Schmitz, “The Senecas' Captive Voice,” review of A Narrative of the Life of Mrs. Mary Jemison by James E. Seaver, Buffalo News, May 7, 1995.

${ }^{43}$ Ibid.

${ }^{44}$ Rebecca Blevins Faery, Cartographies of Desire: Captivity, Race, and Sex in the Shaping of an American Nation. 
${ }^{45}$ Ibid., 186.

${ }^{46}$ Ibid.

${ }^{47}$ Carolyn L. Karcher, ed., Hobomok and Other Writings on Indians by Lydia Maria Child (New Brunswick, New Jersey: Rutgers University Press, 1986), xxx.

${ }^{48}$ Ibid., Xxxi-Xxxii.

${ }^{49}$ Renée L. Bergland, The National Uncanny: Indian Ghosts and American Subjects (Hanover: University Press of New England, 2000), 74-75.

${ }^{50}$ Gordon M. Sayre, ed., American Captivity Narratives: Selected Narratives with Introduction/Olaudah Equiano, Mary Rowlandson, and Others.

${ }^{51}$ Ibid., 378.

${ }^{52}$ The Indians involved were known as Dakotas, Santees, or Eastern Sioux and comprised four divisions: Sissetons, Wahpetons, Wahpekutas, and Mdewakantons. See June Namias, White captives: gender and ethnicity on the American frontier.

${ }^{53}$ Rebecca Blevins Faery, Cartographies of Desire: Captivity, Race, and Sex in the Shaping of an American Nation, 214.

${ }^{54}$ June Namias, White captives: gender and ethnicity on the American frontier.

${ }^{55}$ Ibid.

${ }^{56}$ Ibid.

${ }^{57}$ Ibid., 231.

${ }^{58}$ Carolyn L. Karcher, ed., Hobomok and Other Writings on Indians by Lydia Maria Child.

${ }^{59}$ Kolodny suggests that in the Panther captivity story, the "male wilderness adventure (precursor of the later Western tale) is displaced by a narrative of female adventure; the now standard narrative of female captivity turns instead - and for the first time in American literary history — toward acculturation and accommodation to the wild" (emphasis mine). See Annette Kolodny, "Turning the Lens on 'The Panther Captivity': A Feminist Exercise in Practical Criticism," 335.

${ }^{60}$ John D'Emilio and Estelle B. Freedman, Intimate Matters: A History of Sexuality in America, Second Ed.

(Chicago \& London: The University of Chicago Press, 1997).

${ }^{61}$ Ibid., 107. 
${ }^{62}$ See Ruth Rosen, The World Split Open: How the Modern Women's Movement Changed America (New York: Viking, 2000) for a comprehensive overview of the women's movement in the United States.

${ }^{63}$ Merriam-Webster's Online Dictionary

${ }^{64}$ Aída Hurtado, "The Politics of Sexuality in the Gender Subordination of Chicanas," in Living Chicana Theory, ed. Carla Trujillo (Berkeley: Third Woman Press, 1998), 383.

${ }^{65}$ Herbert Marcuse, One-Dimensional Man: Studies in the Ideology of Advanced Industrial Society (Boston: Beacon Press, 1964), 73.

${ }^{66}$ Herbert Marcuse, Eros and Civilization: A Philosophical Inquiry into Freud (Boston: Beacon Press, 1966), 49. (According to Merriam-Webster's Online Dictionary, polymorphous means "having, assuming, or occurring in various forms, characters, or styles".)

${ }^{67}$ Ibid.

${ }^{68}$ Paul A. Robinson, The Freudian Left: Wilhelm Reich, Geza Roheim, Herbert Marcuse.

${ }^{69}$ Ibid., 216-217.

${ }^{70}$ Ibid., 237.

${ }^{71}$ Herbert Marcuse, One-Dimensional Man: Studies in the Ideology of Advanced Industrial, 158.

${ }^{72}$ Paul A. Robinson, The Freudian Left: Wilhelm Reich, Geza Roheim, Herbert Marcuse, 240.

${ }^{73}$ Herbert Marcuse, An Essay on Liberation (Boston: Beacon Press, 1969).

${ }^{74}$ Ibid, 91.

${ }^{75}$ Rodríguez Milanés explains that she allowed the editor to make the changes because she was "unpublished, the youngest female faculty member, thinking about my contract renewal, the sole income earner for my small family, remembering the unemployment checks and Medicaid cards”. See Cecilia Rodríguez Milanés, “A Journey toward Voice; or, Constructing One Latina's Poetics," in Other Sisterhoods: Literary Theory and U.S. Women of Color, ed. Sandra Kumamoto Stanley (Urbana: University of Illinois Press, 1998), 334.

${ }^{76}$ Chicano, like any label applied to any group, is sometimes a problematic term. It "connotes the proletarian Mexican immigrant experience and later the militancy and celebration of indigenous ancestry" of the Chicano movement, which became especially prominent during the civil rights era. See Patricia Zavella, "Feminist Insider Dilemmas: Constructing Ethnic Identity with 'Chicana' Informants," in Situated Lives: Gender and Culture in Everyday Life, eds. Louise Lamphere, Helena Ragoné and Patricia Zavella (New York: Routledge, 1997), 47. 
Thanks to that ongoing movement, Latinos in the U.S. who are not Mexican-Americans sometimes consider themselves to be Chicanos. The label is not, however, universally accepted by all Mexican-Americans. I use it here to refer to self-described Chicana writers. I use the much more general term "Latino" when discussing people of Latin American heritage and/or Hispanic ethnicity. I use "Mexican" or "mexicano/a" to describe a person from Mexico or of Mexican heritage.

${ }^{77}$ Diana Rebolledo Tey, Women Singing in the Snow: A Cultural Analysis of Chicana Literature (Tucson: University of Arizona Press, 1995).

${ }^{78}$ Sandra Cisneros, "Down There," in The Sexuality of Latinas, eds. Ana Castillo Norma Alarcón, Cherríe Moraga (Berkeley: Third Woman Press, 1993), 22-23.

${ }^{79}$ Mónica Palacios, “Tomboy,” in Living Chicana Theory, ed. Carla Trujillo (Berkeley: Third Woman Press, 1998), 209.

${ }^{80}$ Patricia de La Fuente, “Ana Castillo,” in Chicano Writers: Second Series, eds. Francisco A. Lomelí and Carl R. Shirley (Detroit: Gale Research, Inc., 1992), 63.

${ }^{81}$ Marta A. Navarro, "Interview with Ana Castillo," in Chicana Lesbians: The Girls Our Mothers Warned Us About, ed. Carla Trujillo (Berkeley: Third Woman Press, 1991).

${ }^{82}$ Ana Castillo, Massacre of the Dreamers: Essays on Xicanisma (New York: Plume, 1994); June Nash, “Aztec Women: The Transition from Status to Class in Empire and Colony," in Women and Colonization:

Anthropological Pespectives, ed.s Mona Etienne and Eleanor Leacock (Westport, CT: Bergin \& Garvey Publishers, 1980).

${ }^{83}$ Héctor A. Torres, "Gloria Anzaldúa," in Chicano Writers: Second Series, eds. Francisco A. Lomelí and Carl R. Shirley (Detroit: Gale Research, Inc., 1992), 8-16.

${ }^{84}$ Christine Weiland, “'Within the Crossroads: Lesbian/Feminist/Spiritual Development' An Interview with Christine Weiland (1983)," in Gloria Anzaldúa: Interviews Entrevistas, ed. AnaLouise Keating (New York: Routledge, 2000), 81.

${ }^{85}$ Cherríe Moraga, “Algo Secretamente Amado,” In The Sexuality of Latinas, eds. Ana Castillo and Norma Alarcón, Cherríe Moraga (Berkeley: Third Woman Press, 1993).

${ }^{86}$ Gloria Anzaldúa, Borderlands/La Frontera: The New Mestiza (San Francisco: Spinters/Aunt Lute Book Company, 1987), 150-151. 
${ }^{87}$ McDowell's is an artist colony in Peterborough, New Hampshire.

${ }^{88}$ Christine Weiland, “Within the Crossroads: Lesbian/Feminist/Spiritual Development' An Interview with Christine Weiland (1983)", 115.

${ }^{89}$ Yvonne Yarbro-Bejarano, “Cherríe Moraga,” in Chicano Writers: First Series, eds. Francisco A. Lomelí and Carl R. Shirley (Detroit: Gale Research, Inc., 1989), 165.

${ }^{90}$ Yvonne Yarbro-Bejarano, "De-Constructing the Lesbian Body: Cherríe Moraga's Loving in the War Years," in Chicana Lesbians: The Girls our Mothers Warned Us About, ed. Carla Trujillo (Berkeley: Third Woman Press, 1991), 143.

${ }^{91}$ Cherríe Moraga, "Refugees of a World on Fire: Foreword to the Second Edition," in This Bridge Called My Back: Writings by Radical Women of Color, Second Ed., eds. Gloria Anzaldúa and Cherríe Moraga (New York: Kitchen Table Women of Color Press, 1983), unnumbered page.

92 Ibid.

${ }^{93}$ Gloria Anzaldúa, "La Prieta," in This Bridge Called My Back: Writings by Radical Women of Color, Second Ed., eds. Gloria Anzaldúa and Cherríe Moraga (New York: Kitchen Table Women of Color Press, 1983 ), 209.

${ }^{94}$ Ana Castillo, Massacre of the Dreamers: Essays on Xicanisma, 134.

${ }^{95}$ Diana Rebolledo Tey, Women Singing in the Snow: A Cultural Analysis of Chicana Literature, 202.

${ }^{96}$ Ana Castillo, Massacre of the Dreamers: Essays on Xicanisma, 128.

${ }^{97}$ Ibid., 132.

${ }^{98}$ Ibid., 133.

${ }^{99}$ Ibid., 135.

${ }^{100}$ Cherríe Moraga, "La Güera," in This Bridge Called My Back: Writings by Radical Women of Color, Second Ed., eds. Gloria Anzaldúa and Cherríe Moraga (New York: Kitchen Table Women of Color Press, 1983 ), 30.

${ }^{101}$ Gloria Anzaldúa, "La Prieta," in This Bridge Called My Back: Writings by Radical Women of Color, Second Ed., 207.

102 Herbert Marcuse, An Essay on Liberation.

${ }^{103}$ Paul A. Robinson, The Freudian Left: Wilhelm Reich, Geza Roheim, Herbert Marcuse, 196. 